\title{
Research on the Right to Use Rural Homestead in China
}

\author{
Lingyan Lv \\ China University of Geosciences \\ Wuhan, China
}

\begin{abstract}
Rural land is the basis for the survival and development of farmers and has always been the focus of attention of the state and society. The rural homestead and the rural housing above it, as an important livelihood security property of farmers, have been playing a stable use function, but their asset capital function has not been effectively realized for a long time. Farmers enjoy the right to use homestead, and the connotation, legal characteristics and the relationship between the right to use and ownership of this " right to use" have a direct impact on farmers' concrete exercise of this right. Therefore, the research on the right to use homestead not only concerns the interests and property of farmers' housing security, but also the rural land rights relations and the construction and improvement of the new rural land rights system.
\end{abstract}

Keywords-Rural land; The right to use homestead; Institutional research

\section{EVOLUTION OF THE RIGHT TO USE HOMESTEAD SYSTEM}

\section{A. Private Ownership of Homestead}

After the founding of the People's Republic of China, our country has established a land system privately owned by peasants, who has the ownership of homestead. During the period of primary cooperatives, the Land Reform Law of 1950 clearly stated: "Abolish the land ownership of feudal exploitation by the landlord class and implement the land ownership of farmers". Farmers can buy, sell, mortgage, rent and inherit homestead, establishing farmers' ownership of land and houses, and farmers enjoy almost complete ownership of cultivated land and homestead. At the stage when land is privately owned by farmers, the state gives farmers full land rights, and farmers can dispose of their land according to law after obtaining land ownership certificates[1]. The 1954 Constitution of China also clearly stipulates the protection of farmers' land ownership. In the period of senior cooperatives, the second paragraph of Article 16 of the Model Regulations for Senior Agricultural Production Cooperatives, adopted on June 30, 1956, stipulates that agricultural houses and land owned by members before that time need not be classified as senior cooperatives. This shows that even in the period of senior cooperatives, the provisions of the previous period of primary cooperatives have been continued. There has not been much substantial change in farmers' land rights, and farmers still enjoy homestead ownership.

In this historical period, just after the founding of New China, due to the influence of the social and historical conditions at that time, all systems were not perfect and social development was also in the exploratory stage. The homestead at that time was owned by the farmers themselves. In order to truly realize the status of the people as masters of their own affairs and to maximize the interests of the people, homestead is allocated on an individual basis and also obtained free of charge, guaranteeing farmers' basic right to subsistence. In addition, it also stipulates that the ownership of the homestead and the ownership of rural housing are owned by farmers, allowing them to rent, buy, sell and mortgage the homestead. This shows that the homestead system at this stage has played a dual role of security and property.

\section{B. Collective Ownership of Homestead}

With the completion of the Three Great Remould in 1956, the land changed from private to public. After entering the people's communalization movement, the ownership of rural homestead changed from peasant ownership to collective ownership. Under the historical conditions at that time, in order to improve production efficiency, the ownership of homestead belongs to the rural collective economic organizations, while farmers lost ownership and only retained the right to use it. At the same time, the punishment right which the Land Reform Law gives farmers was restricted or prohibited. During this period, the rural homestead was distributed by households. The right to use homestead has been separated from the ownership, and there is duality in the distribution of the subject of power and which boundaries are not very clear. Farmers only enjoy the right to use and the ownership of agricultural houses, but this right has also been greatly restricted, such as not being allowed to circulate, mortgage, transfer, etc. However, there is no restriction on the ownership of houses on the homestead. This shows that the homestead system at this stage pays too much attention to the security of homestead but ignores its property.

Until the reform and opening up, the state has strictly restricted the transfer of the right to use homestead. For example, Article 3 of the State Council's Emergency Notice on Preventing Rural Housing from Seizing Cultivated Land in 1981 stipulates: " For homestead assigned to members, members only have the right to use it, and are not allowed to rent, buy, sell or transfer without authorization, nor to build houses, etc.[3]" The second paragraph of Article 15 of the Regulations on the Administration of Land for Building Houses in Villages and Towns in 1982 stipulates" Anyone who sells or rents a house shall not apply for homestead 
again.[4]" This provision has also included houses on the homestead in the ban on circulation, which is stricter than the previous provision. Article 38 of the Land Administration Law in 1986 stipulates that the application for homestead after selling or renting houses shall not be approved[5]. This provision continues and reinforces the previous provision. It can be seen from this that the homestead system in each period has the historical color of that time, and its functions and purposes are different. However, with the gradual disintegration of the urban-rural dual structure, the function of homestead has gradually changed, and the current homestead system has gradually failed to meet the needs of the current rural social development.

\section{Connotation Analysis of Homestead Use Right}

\section{A. Definition of the right to use homestead}

Homestead is the land owned and used by farmers for building houses and their ancillary facilities, including houses already built and land decided to be used for building houses[6]. Its ownership belongs to rural collective economic organizations, while farmers only enjoy the right to use homestead. The concept of the right to use rural homestead first appeared in the Notice on Some Supplementary Provisions for Members' Homestead Issues. Since the right to use homestead is unique to our country and our land system is premised on public ownership, we cannot directly transplant a ready-made legal system from other countries or regions with private ownership of land. At present, the academic research on the concept of the right to use homestead mainly focuses on the characteristics and legal nature of the right to use homestead. The "Property Law" does not clearly define the right to use the homestead, and its article 152 only stipulates the right of the homestead owner to use the homestead. For this issue, scholars also have their own definitions of the right to use homestead. For example, Professor Wang Liming believes that the right to use homestead means 'the right to occupy and use collectively owned land for the purpose of building houses and ancillary facilities". Professor Wei Zhenying believes that the right to use homestead refers to " the right of members of rural collective economic organizations to build individual houses and their ancillary facilities on the land collectively owned by farmers according to law[7]."

To sum up, the right to use homestead refers to an exclusive right of farmers who are members of collective economic organizations to occupy and use collectively owned land based on their exclusive identity and can only use houses for the main purpose. This right is a dynamic development process, an expansionary right and a right to gradually transition from occupation and use to income and disposal.

\section{B. Legal features of the right to use homestead}

At present, there are mainly four views in academic circles on the legal characteristics of the right to use homestead. The first is the "Three Attributes" theory. Wang Liming advocates that the right to use homestead has the characteristics of identity, usufructuary right and quantity limitation. The second view is the "Five Attributes" theory. Liu Jun advocates that the right to use homestead has the characteristics of identity, gratuitousness, subordination, household unit and area equality. The third view is the "six attributes" theory. Yin Fei argues that the right to use homestead is subject - limited, object - limited, use - limited, free of charge, indefinite and prohibited from circulation. The fourth view is the "seven attributes" theory. Shen Jianping advocates that the right to use homestead has the characteristics of identity, specificity, gratuity, unlimited duration, restriction of use, restriction of circulation and uniqueness of original quantity[8]. It can be seen from this that its legal characteristics are not clearly defined, but can be summarized from relevant systems and relevant laws and regulations. According to the specific legal provisions, Article 62 of the Land Administration Law stipulates that every family in the countryside can only have one homestead. Article 152 of the Property Law stipulates that rural residents can occupy homestead and can build rural houses and other related living facilities on the homestead. At the same time, both the Guarantee Law and the Property Law stipulate that the right to use homestead shall not be mortgaged. It can be seen from this that its legal characteristics are mainly reflected in the following two aspects:

First, the right to use homestead has identity, which is a right born on the basis of exclusive identity. First of all, homestead is a special object enjoyed by people with a specific identity and with a specific purpose. Secondly, the homestead has been labeled as a member of the rural collective economic organizations, and it has the property of specific identity interests. And it is arranged by a specific legal system of rural collective membership, exists in a stable framework of rural collective membership and family membership of farmers, and is an identity based on exclusive membership.

Second, the incomplete usufructuary right, China's property law stipulates the right to use homestead as usufructuary right, and usufructuary right itself is a private right. Focusing on the use value of property and according to this logic, the right to use homestead should also be a private right." A complete private property right should include at least three basic contents: exclusive right to use, exclusive right to benefit and free right to transfer[9]." The right to use the homestead itself contains the dual attributes of public and private rights. Although our law gives the usufructuary right attribute to the right to use the homestead, it also restricts its circulation and disposition to a certain extent, and its property attribute is not fully developed. The incomplete property right of usufructuary rights hinders the development of mortgage reform of homestead use right to a certain extent.

\section{RELATIONSHIP BETWEEN THE RIGHT TO USE HOMESTEAD AND THE OWNERSHIP OF RURAL HOUSING}

In fact, the real premises relations are the relationship between buildings and land. There are two legislative models in the civil law system for the relationship between houses and land under them, namely, unification and separateness. The representative country of unionism is Germany. They claim that the buildings on the land are part of the land and they are a unified whole. The representative of separatism is Japan and Taiwan. Due to the public ownership of land in our 
country, we have adopted the model of integration of building ownership and land use rights, but its essence is still the integration of premises.

\section{A. "One Premise" and "Separation of Premises"}

China's law regards land and buildings on the ground as two objects. Homestead and rural houses belong to different types of property, but they have a unique relationship. Rural housing can't exist independently from the homestead in physical state. Rural housing should be built on the basis of homestead, and homestead is for the purpose of building farmers' houses and their ancillary facilities and can't be used for other purposes. It includes residential land including residential foundation and ancillary facilities to meet farmers' basic living needs. Like other types of land, homestead has both public and private interests, while rural housing is a private property built by farmers. The homestead and the farm house are an inseparable whole in physical appearance, and they cannot be separated in external nature. However, the two are independent in terms of rights allocation. As farmers' private property, rural housing can be disposed of. However, farmers only have limited right to use the homestead and do not have the right to dispose of it. Inconsistency in rights allocation makes them have certain obstacles in the mortgage process. In our country, the principle of "following the house" is generally adopted in practice, that is, tying together the homestead right and the house right on the homestead which can be said to be a mixed legislative model of monism and dualism.

\section{B. Comparison and Analysis}

Although our country adopts the principle of "real estate integration[10]", there are different views in academic circles on this issue. Some scholars advocate "integration of real estate" while others advocate "separation of real estate". Scholars who adhere to the principle of separation of real estate believe that at present, the overall social environment and social security system in rural areas in our country are not very sound, so we should carry out gradual changes over the existing homestead system. The separation of real estate does not mean the physical separation of the house from the homestead under it, but the separation of the right to use the homestead from the ownership of the house on it, which is actually a separation of rights. At present, the right to use the homestead in our country belongs to the same person as the ownership of the rural housing above it, while the principle of separation of real estate breaks this identity and believes that these two rights can't belong to the same person. In real life, there is a separation of real estate. For example, many rural residents have changed from rural household register to nonagricultural household register due to migrant workers and school attendance, and thus have lost the right to use the homestead because they have lost their membership in the rural collective economic organizations. However, they still enjoy the ownership of the house above the homestead, and the ownership of the house does not have identity characteristics. Therefore, the principle of separation of real estate has its practical basis.

However, the practical basis for adopting the principle of "one house, one place" is that the house and the place cannot be physically separated. From the perspective of ownership, the "one house, one place" is conducive to simplifying the real right relationship, preventing disputes over rights and reducing transaction costs, and can avoid the situation that the ownership of houses is not attached by different owners of houses. Therefore, the "one house, one place" on the right to use homestead has become the prevailing view in academic circles. However, the question is, what should the "land" here refer to? As we all know, the "land" in the "integration of real estate" in a city does not refer to the ownership of land, but the right to use construction land. Scholars have different views on whether the principle of housing integration is applicable to rural homestead [11]. However, most scholars hold a supportive attitude.

\section{CONCLUSION}

The right to use homestead is a special usufructuary right system in China, which mainly guarantees farmers' basic right to subsistence and is of social welfare. However, with the improvement of rural social and economic level, the right to use homestead in rural areas has gradually transitioned from social security to property. Studying the system evolution of homestead to grasp its historical development law is to meet the needs of the new rural land rights system construction.

At present, the most important issue is the property of the right to use the homestead itself, which is limited by its identity and therefore has not been fully developed. The right to use homestead develops with the history of our country, and this right is the exclusive right granted to farmers by the state. It is well known that the right to use homestead has a strong identity and is a right with social welfare. However, the identity and property of the right to use the homestead can't be developed in a balanced way gradually. Realizing the complete property requires breaking through the identity of the right to use the homestead and treating the right to use the homestead as a property right divorced from a rural identity. Clarifying the relationship between the right to use the homestead and the ownership of the rural house will help clarify the property of the right to use the homestead, promote the integration of its identity and property, and exert its maximum utility[12].

To sum up, the system of right to use homestead cannot be perfected overnight, and the various systems are not perfect enough, which requires further study.

\section{REFERENCES}

[1] Wang Xiaoying. Study on the Right to Use Rural Homestead in China [M]. China Democratic and Legal Publishing House, 2014.

[2] Liu Daoyuan. Research on Legal Innovation of Collective Land Transfer [M]. Peking University Press, 2011.

[3] Xu Hanming, Liu Chunwei. Research on Farmers' Willingness to Transfer Homestead Use Right and Its Influencing Factors - Based on a Questionnaire Analysis of 210 Households in Jiangxia District of Wuhan [J]. Journal of Northwest Agriculture and Forestry University (Social Science Edition), 2012: 12 (6).

[4] Zhang Hongxiao. Policy and legal research on the circulation system of rural land contractual management rights [M]. China Forestry Press, 2010 edition. 
[5] Zhang Guohua. On the transferability and realization of the right to use homestead [M]. Law Press, 2013.

[6] Yang Hui. Study on the legal system of land use control [M]. Law Press, 2010.

[7] Wang jun - min. legislative basis and path selection of China's agricultural land system[M]. China university of political science and law press, 2011.

[8] Yuan Jinxiu. Research on the Legal Issues of Rural Homestead Use Right [M]. China Commerce Press, 2013.
[9] Guo Zhonghao. On the construction and improvement of the usufructuary right attribute of homestead use right [J]. Journal of huaihua university, 2016 (2).

[10] Tao Zhongtaro, Yang Huan. Analysis of farmers' housing property rights - looking for the agreement between policies and laws [J]. Inner Mongolia Social Sciences (Chinese version), 2016 (5).

[11] Zhang Guohua. On the function of homestead use right [J]. Tianjin Law, 2013 (3).

[12] Yu Xiao. Legal reform of homestead from the perspective of Sino British comparison [M]. Shanghai: Shanghai People's Publishing House, 2013: $11-12$ 